\title{
Perbedaan Profil Protein Produk Olahan (Sosis) Daging Babi dan Sapi Hasil Analisa SDS-PAGE
}

\author{
${ }^{1}$ Sandra Hermanto*, ${ }^{2}$ Cut Dhien K. Meutia \\ ${ }^{1)}$ Program Studi Kimia FST UIN Syarif Hidayatullah Jakarta \\ ${ }^{2)}$ Program Studi Biologi FST UIN Syarif Hidayatullah Jakarta \\ Jalan Ir. H. Juanda No 95 Ciputat Jakarta 15412 Indonesia \\ e-mail : $\underline{\text { shmt75@yahoo.com }}$
}

\begin{abstract}
Abstrak
Meningkatnya kebutuhan konsumsi protein hewani, khususnya daging tidak luput dari beragam masalah, di antaranya kekhawatiran adanya kandungan babi sebagai bahan baku dalam produk olahan (sosis). Tujuan dari penelitian ini adalah untuk mengetahui profil protein daging sapi dan babi dalam keadaan mentah dan produk olahan (sosis) berdasarkan karakteristik berat molekul (BM) sebagai dasar untuk pengembangan metode analisa kehalalan pangan. Penelitian diawali dengan isolasi protein dari daging mentah (sapi dan babi) dan sosis (sapi dan babi) yang meliputi sosis komersil dan olahan sendiri. Isolat protein yang dihasilkan dari masing-masing sampel dikarakterisasi dengan Sodium Dodecyl Sulphate Polyacrylamide Gel Electrophoresis (SDS-PAGE) 10\%(v/v) untuk mengetahui BM $(\mathrm{kDa})$ protein terlarut. Penghitungan BM dilakukan melalui regresi linear $\mathrm{y}=-0,9259 \mathrm{x}+2,2188$ dengan $\mathrm{R}^{2}=0,9662$, yang diperoleh dari protein standar sebagai marker. Hasil penelitian yang dilakukan menunjukkan terdapat 3 pita spesifik pada sapi mentah yang tidak dimiliki babi mentah yaitu pada Rf 0,29; 0,71; dan 0,88 dengan BM sekitar 89,2 kDa; 36,4 kDa dan 25,3 kDa. Selain itu pada sosis sapi komersil ditemukan pita tebal dengan BM sekitar $45,1 \mathrm{kDa}$ dan pada sosis babi komersil ditemukan pita tebal dengan BM sekitar $69 \mathrm{kDa}$. Secara keseluruhan, pada sampel sosis, protein yang terkandung sulit untuk dikarakterisai dengan elektroforesis SDS-PAGE karena sebagian protein tersebut telah terdegradasi.
\end{abstract}

Kata kunci : Sosis, Sapi dan Babi, Profil Protein, SDS-PAGE

\begin{abstract}
The increasing of animal protein consumption, especially meat products created some crucial problems in the moslem society because of probably the meat products such as sausage and processing meat are contaminated by pork derivated. The primary objective of this research is to find out the different of protein profile from beef and pork in raw material and suasage based on molecular weight (MW) characteristic as a preface to develope of food halalness method. This research was started by protein isolation of beef and pork in raw material and sausages. The sausages used in this experiment carried out from local market and fresh meat got from slaughterhouse. The protein isolates from each samples were analyzed by SDS-PAGE $10 \%(\mathrm{v} / \mathrm{v})$ to detect of whole saturated protein which is characterized by measuring of molecular weight (MW). The measurement of MW using protein standar marker from Biorad, with equation $y=-0,9259 x+2,2188$ and coefficient of determination $R^{2}=0,9662$. The result of this experiment showed that there are three specific bands of beef protein extract which can't be found in pork protein extract, i.e. in $\mathrm{Rf}$ of 0,$29 ; 0,71$ and 0,88 where the molecular weight around 89,2 $\mathrm{kDa}$, $36,4 \mathrm{kDa}$ and 25,3 $\mathrm{kDa}$ respectively. In another case, beef comercial sausage provide a bold band with MW around 45,1 kDa while in comercial pork sausage provide a bold band in $69 \mathrm{kDa}$. The whole study of this SDS-PAGE electrophoresis however did not give a satisfy results due to a some degradation of proteins.
\end{abstract}

Key words : Sausage, beef and pork, Protein profile, SDS-PAGE 


\section{PENDAhuluan}

Pengaruh era globalisasi telah membawa dampak yang sangat besar dalam peredaran dan ketersediaan produk pangan, dimana berbagai jenis bahan pangan baik produk lokal maupun produk import beredar luas di pasaran. Lebih jauh lagi, produkproduk pangan yang diimport telah mampu bersaing secara kompetitif dengan produkproduk pangan lokal. Sayangnya, banyak produk-produk pangan yang diimport tersebut, masih diragukan kehalalannya karena ketidakjelasan dokumen sertifikasi halal serta proses pelabelannya.

Kehalalan suatu produk pangan sangat penting dijadikan pertimbangan dalam mengkonsumsi produk pangan. Sebagaimana Allah SWT berfirman dalam surat Al-Baqarah ayat 173, "Hanya yang diharamkan atas kamu ialah bangkai, darah, daging babi dan hewan yang disembelih bukan dengan nama Allah melainkan dengan nama berhala. Tetapi barang siapa yang terpaksa memakannya, sedang ia tiada aniaya dan tiada pula melampaui batas, maka takada dosa terhadapnya. Sungguh Allah Maha Pengampun Lagi Maha Penyayang “

Untuk kategori makanan hasil olahan, kehalalan suatu produk pangan sangat tergantung pada halal dan haramnya bahan baku dan tambahan serta tergantung pula pada proses. Menurut Apriyantono, dkk, (2007), salah satu jenis produk olahan hewani yang dapat dinilai paling rawan dari segi kehalalannya ialah sosis karena selalu menggunakan unsur babi dalam pembuatannya, yaitu berupa daging babi, tetelan babi, hati babi, atau selongsong sosis yang terbuat dari gelatin babi maupun lemak babi.

Suryaningsih (1997) mengatakan, sosis merupakan salah satu produk olahan daging yang banyak disukai masyarakat Indonesia. Makanan olahan ini terbuat dari daging yang dihaluskan, dibumbui, dan dibungkus dengan casing sehingga memiliki rasa yang khas dan ukuran yang simetris. Selama ini bahan baku sosis sebagian besar adalah daging sapi, walaupun ada juga yang berasal dari daging babi maupun ayam.

Adanya kekhawatiran perihal bahan baku sosis itulah yang kiranya perlu dicermati masyarakat untuk lebih selektif dalam memilih produk pangan berbahan baku hewani. Salah satu cara yang dapat dilakukan untuk menganalisis produk pangan terutama yang berbahan baku hewani yang telah mengalami pencampuran adalah dengan cara membandingkan komposisi protein pada masing-masing sampel, baik sampel mentah maupun sampel dari bahan percampuran.

Penelitian yang dilakukan Susanto (2006), menyatakan bahwa hasil karakterisasi fraksi protein daging babi mentah dengan metode elektroforesis SDS-PAGE menunjukkan terdapatnya protein yang tidak diketahui dengan berat molekul $112,13 \mathrm{kDa}$ dan tidak terdapat pada daging sapi mentah. Kemudian ditemukan protein tropomiosin 1 pada daging babi rebus dan protein tersebut terdeteksi pula pada daging sapi rebus. Selain itu terdapat pula perbedaan lain yaitu adanya protein desmin pada daging babi rebus yang tidak ditemukan pada daging sapi rebus.

Li et al (1997), mengatakan bahwa protein desmin memiliki berat molekul sekitar $52 \mathrm{kDa}$. Untuk mengembangkan penelitian lebih lanjut, diperlukan modifikasi pegujian terhadap sampel daging yaitu dalam keadaan mentah sebagai kontrol positif dan produk olahan (sosis) yang diperoleh dari pasar (komersil) maupun sosis buatan sendiri.

Karakterisasi profil protein dilakukan dengan pemisahan protein menggunakan elektroforesis SDS-PAGE yang dilanjutkan dengan pengukuran waktu retensi (Rf) untuk mengidentifikasi profil protein pada masingmasing sampel.

\section{METODE PENELITIAN}

\section{Bahan dan Alat}

Bahan-bahan yang digunakan adalah daging sapi mentah dari rumah potong hewan (RPH) Kecamatan Ciputat; daging babi mentah dari RPH Cililitan Jakarta Timur; sosis 
sapi dan sosis babi yang berasal dari pasar Ciputat dan sosis buatan sendiri, sodium dodecyl sulfate (SDS) 10\%; Lowry I dan Lowry II (Lampiran 7), Gel Acrylamide solution (30\% T; 2,67C) Bio-Rad; Bisacrylamide Sigma, Resolving Buffer (Tris- $\mathrm{HCl}$ 1,5M pH 8,8 Bio-Rad); Stacking Buffer (Tris$\mathrm{HCl}$ 0,5M pH 6,8 Bio-Rad); Ammonium peroksida disulfate (APS) $10 \%$; N,N,N'N'Tetramethylethylenediamine (TEMED); Phosphate-buffered saline (PBS) 0,01 M pH 7,2; Running buffer Sigma; Staining solution coomasie blue R-250 Bio-Rad;

Alat-alat yang digunakan meliputi Blender, Gridingmill, Pisau, Timbangan analitik, Tabung eppendorf, Tabung sentrifuge, Macrosentrifuge Sorvall, Microsentrifuge Sorvall dan Sonikator Branson 2210 untuk isolasi protein dari jaringan hewan. Spektrophotometer UV/Vis Lambda 25 Perkin Elmer untuk pengukuran kadar protein dan MiniProtean III Cell Electroforesis (Bio-Rad) untuk pemisahan dan karakterisasi protein. Analisa BM dilakukan dengan menggunakan software Lab Images 2006.

\section{Ekstraksi Protein dari Jaringan Daging Segar dan Sosis (Sapi \& Babi)}

Masing-masing sampel (daging segar dan sosis) sapi dan babi ditimbang $10 \mathrm{~g}$ dan ditambahkan $20 \mathrm{ml}$ PBS 0,01 M pH 7,2 dalam $\mathrm{NaCl}$ 0,5 M, lalu diblender. Pada suhu $4^{\circ} \mathrm{C}$, diambil $5 \mathrm{ml}$ filtrat lalu disonikasi selama 10 menit. Kemudian ditambahkan $3 \mathrm{ml}$ buffer PBS 0,01 $\mathrm{M}$ pH 7,2, lalu disentrifus lagi dengan kecepatan $6000 \mathrm{rpm}$ selama 15 menit pada suhu $4^{\circ}$ C. Supernatan yang terbentuk disimpan dalam dua tabung eppendorf pada suhu $-20^{\circ}$ C. (James D. \& Howland K., 1997)

\section{Pengukuran Kadar Protein (Lowry, 1959)}

Penentuan kadar protein dilakukan menurut metode Lowry, yakni dengan menggunakan $1 \mathrm{~mL}$ larutan A $(20 \mathrm{mM}$ $\mathrm{CuSO}_{4} .5 \mathrm{H}_{2} \mathrm{O}$ dan $30 \mathrm{mM}$ Na-sitrat) dan $50 \mathrm{~mL}$ larutan $\mathrm{B}\left(0,1 \mathrm{M} \mathrm{Na} \mathrm{CO}_{3}\right.$ dan $\left.0,1 \mathrm{M} \mathrm{NaOH}\right)$. Campuran reaksi dihomogenkan dengan vortex dan didiamkan selama 10 menit. Selanjutnya larutan D (regen Folin ciocalteu $1 \mathrm{~N}$ ) sebanyak 0,25 mL ditambahkan ke dalam campuran reaksi, dihomogenkan dengan vortex dan didiamkan selama 30 menit. Campuran reaksi diukur pada $\lambda 750 \mathrm{~nm}$ dan konsentrasi protein ditentukan dengan kurva standar bovine serum albumin (BSA).

\section{Pemisahan dan Karakterisasi Protein dengan SDS-PAGE (Hames, 1998)}

\begin{abstract}
Profil protein dikarakterisasi dengan SDS-PAGE (sodium dodecyl sulphate poliacrilmide gel electrophoresis) yang dilakukan dengan menggunakan metode standar (Hames, 1998).. Sampel protein didenaturasi dengan buffer sample (Tris-Cl $150 \mathrm{mM} \quad \mathrm{pH} \quad 6.8, \quad$ SDS $6.25 \%, \quad \beta-$ merkaptoetanol, gliserol 25\%, bromophenol blue 2,5 $\mathrm{mM}$ ) dengan perbandingan protein dan buffer 4:1, dan dididihkan selama 10 menit serta disentrifugasi selama 5 menit. Elektroforesis dilakukan pada tegangan 150 volt selama 45 menit. Untuk staining protein digunakan Coomasie briliant blue $0.1 \%$ (w/v).
\end{abstract}

\section{Analisa Bobot Molekul Protein hasil SDS- PAGE}

Analisa bobot molekul (BM) masingmasing protein hasil ekstraksi jaringan daging segar dan sosis sapi dan babi dilakukan dengan menggunakan program aplikasi Lab Image 2006, dengan menggunakan protein Marker sebagai standar. Hasil scaning pita-pita protein dipetakan ke dalam kurva persamaan regresi linier sehingga didapatkan nilai BM protein pada masing-masing sampel.

\section{HASIL DAN PEMBAHASAN}

\section{Konsentrasi Protein Total}

Dari ke empat sampel jaringan daging segar dan sosis (sapi dan babi) dengan bobot cuplikan yang relatif sama diperoleh kadar protein yang berbeda seperti terlihat pada tabel 1. 
Tabel 1. Kadar protein masing-masing sampel

\begin{tabular}{|l|l|c|}
\hline No & \multicolumn{1}{|c|}{ Sampel } & $\begin{array}{c}\text { Konsentrasi } \\
(\mathrm{mg} / \mathrm{mL})\end{array}$ \\
\hline 1 & Daging Sapi mentah & 612,17 \\
\hline 2. & Daging Babi mentah & 685,99 \\
\hline 3. & Sosis sapi & 225,08 \\
\hline 4. & Sosis babi & 265,18 \\
\hline
\end{tabular}

Konsentrasi protein pada daging sapi mentah lebih rendah dibandingkan dengan daging babi mentah, namun demikian perbedaan konsentrasi protein total antara sapi dengan babi mentah tidak berbeda signifikan. Adanya perbedaan pada konsentrasi tersebut diduga karena berbedanya jaringan otot yang diambil saat perlakuan isolasi protein. Jaringan otot pada sapi yang diambil adalah bagian paha belakang dan pada babi yang diambil adalah bagian punggung. Selain itu diduga pula karena perlakuan pada saat ekstraksi protein belum optimal.

Demikian pula pada perlakuan isolasi protein pada sampel sosis, di mana sampel sosis sapi maupun sosis babi yang diekstraksi sebanyak $10 \mathrm{~g}$ menghasilkan konsentrasi protein total yang bervariasi. Konsentrasi protein sosis sapi adalah 225,08 $\mathrm{mg} / \mathrm{ml}$ sedangkan konsentrasi protein sosis babi adalah 265,18 mg/ml. Perbedaan konsentrasi pada kedua sample sosis dimungkinkan karena perbedaan sumber daging serta proses pengolahannya.

Alamsyah (2008), mengatakan bahwa penghancuran daging bertujuan untuk memecah dinding sel serabut otot sehingga protein dapat terekstraksi dengan larutan garam. Gesekan dengan alat penghalus dapat mengakibatkan terhambatnya ekstraksi protein sehingga terjadi koagulasi protein.

Adanya perbedaan konsentrasi protein total pada daging mentah dengan daging olahan (sosis) diduga karena saat ekstraksi daging mentah jumlah daging yang digunakan lebih banyak dan tanpa adanya perlakuan pemanasan atau penguringan, sehingga konsentrasi proteinnya tinggi. Sedangkan pada sosis didapat nilai konsentrasi yang rendah karena pada sosis menggunakan jumlah daging sedikit, dilakukan proses penguringan dan dalam pembuatannya dilakukan proses perebusan dengan suhu $80^{\circ} \mathrm{C}$ selama 15 menit. Dengan demikian perlakuan pemanasan dan penguringan dapat mengakibatkan denaturasi protein sehingga konsentrasi protein total terlarut menjadi lebih rendah (Wahniyati \& Ali, 2005).

\section{Profil protein hasil SDS-PAGE}

Karakterisasi profil protein dilakukan dengan menggunakan Mini protean Gel Electrophoresis, dengan konsentrasi akilamid/bis-akrilamid 10\%(v/v). Hasil pemisahan dengan SDS-PAGE dapat dilihat pada gambar 1.

Sampel percobaan dibagi ke dalam 3 kelompok yaitu kelompok 1 terdiri dari sampel sapi dan babi mentah (SM dan BM); kelompok 2 yaitu sosis sapi dan babi komersil dengan cara pembuatan yang dianggap sama $(2 \mathrm{~K}$ dan $1 \mathrm{~K})$ dan kelompok 3 yaitu sosis sapi dan babi buatan sendiri (2B dan 1B).

Dari hasil elektroforesis tersebut, pada kisaran berat molekul (BM) 21,5-116 kDa, daging sapi mentah menghasilkan 17 buah pita protein dan babi mentah menghasilkan 14 buah pita protein. Pita terbanyak terbentuk pada kisaran BM 31-66,2 kDa. Pada sapi mentah ditemukan 3 buah pita protein

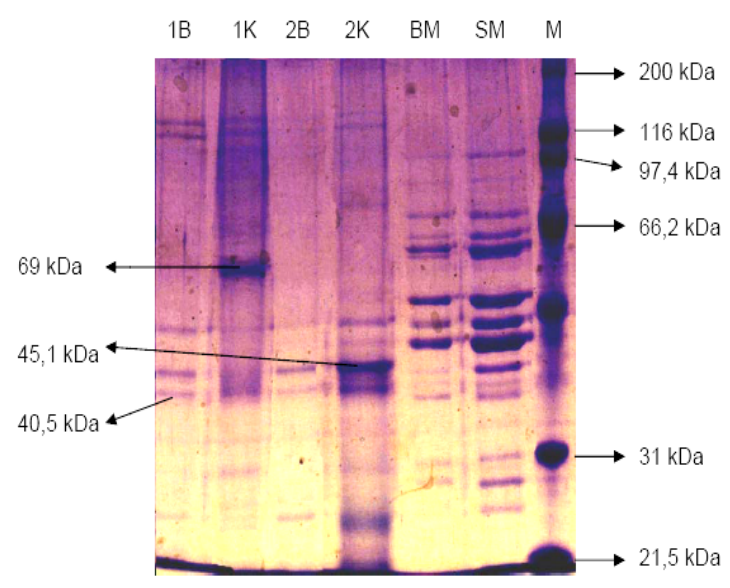

Gambar 1. Hasil elektroforesis SDS-PAGE (1B\&1K: Sosis babi, 2B \& 2K : Sosis Sapi, BM : Daging babi mentah, SM : Daging sapi mentah, M : Protein Marker) 
pembeda yang tidak dimiliki babi mentah yaitu pada Rf 0,$29 ; 0,71$ dan 0,88 dengan $\mathrm{BM}$ secara berurut sekitar $89,2 \mathrm{kDa}, 36,4 \mathrm{kDa}$ dan 25,3 $\mathrm{kDa}$.

Pada sosis babi komersil ditemukan pita protein sebanyak 9 buah dan sosis babi buatan sebanyak 8 buah pita protein dengan intensitas rendah. Pita terbanyak terbentuk pada kisaran BM 31-66,2 kDa. Ditemukan pula kesamaan pita yang terbentuk pada babi mentah (kontrol) maupun sosis babi (komersil dan buatan) yakni pada BM sekitar 40,5 kDa dan 53,4 kDa. Hal ini menunjukkan bahwa protein pada BM tersebut muncul pada daging babi dalam keadaan mentah maupun telah mengalami proses pengolahan walaupun dengan intensitas yang bebeda.

Perbedaan antara sosis sapi komersil dengan sosis babi komersil adalah ditemukannya 1 pita protein dengan intensitas tinggi pada sosis sapi komersil dengan BM sekitar 45,1 kDa yang tidak ditemukan pada sosis babi komersil. Sebaliknya, pada sosis babi komersil ditemukan 1 pita protein dengan intensitas tinggi dengan BM sekitar $69 \mathrm{kDa}$ namun tidak terlihat pada sosis sapi komersil. Protein dengan BM sekitar $69 \mathrm{kDa}$ juga ditemukan pada sosis babi buatan sendiri namun tidak terlihat pada sosis sapi.

Adanya perbedaan signifikan yang terlihat pada pita protein sampel sapi dan babi menunjukkan adanya keragaman genetik dalam suatu spesies yang disebabkan ketidakhomogennya genetik dari setiap spesies. Menurut Nazar (2007), apabila terdapat pita pada satu spesies yang tidak ditemukan pada spesies lain ataupun sebaliknya, maka dapat dikatakan spesifik walaupun kemunculannya bervariasi.

Secara keseluruhan, dari hasil SDSPAGE ini menunjukkan bahwa tidak ditemukan adanya spesifitas protein dalam bentuk pita spesifik pada sample mentah terhadap produk sosis yang dapat dijadikan marker berat molekul protein. Hal ini dapat dijelaskan dengan melihat adanya kesamaan 1 pita protein dengan BM sekitar 40,5 kDa yang muncul pada semua sampel baik mentah (kontrol) maupun sosis. Selain itu, kemunculan pita protein pada kelompok sapi baik mentah maupun sosis dengan BM sekitar 25,3 $\mathrm{kDa}$ bukan merupakan pita spesifik karena pita tersebut juga muncul pada sosis babi buatan. Protein yang terlihat

pada sampel produk olahan (sosis) dimungkinkan sudah terdenaturasi bahkan terdegradasi akibat pengaruh proses pengolahan produk pangan. Namun demikian, spesifitas pita protein pada produk olahan sosis (sapi dan babi) dapat dibedakan satu sama lain berdasarkan pita protein yang spesifik pada kisaran 45,1 $\mathrm{kDa}$ untuk sosis sapi dan $69 \mathrm{kDa}$ untuk sosis babi.

\section{KESIMPULAN}

Dari hasil penelitian yang telah dilakukan, diperolah kesimpulan sebagai berikut :

1. Terdapat 3 buah pita protein yang menjadi pita pembeda pada ekstrak daging sapi mentah yang tidak dimiliki daging babi mentah yaitu pada Rf 0,$29 ; 0,71$ dan 0,88 dengan BM secara berurut sekitar 89,2 $\mathrm{kDa}, 36,4 \mathrm{kDa}$ dan 25,3 kDa.

2. Spesifitas pita protein pada produk olahan sosis (sapi dan babi) dapat dibedakan satu sama lain berdasarkan pita protein yang spesifik pada kisaran 45,1 kDa untuk sosis sapi dan $69 \mathrm{kDa}$ untuk sosis babi komersil.

\section{UCAPAN TERIMA KASIH}

Pada kesempatan ini penulis mengucapkan terimakasih kepada FST UIN Syarif Hidayatullah Jakarta yang telah mendanai penelitian ini. Kepada Kepala Pusat Laboratorium Terpadu UIN beserta seluruh staff dan dosen Program Studi Kimia FST UIN Syahid Jakarta atas segala fasilitas dan dukungan yang telah diberikan.

\section{DAFTAR PUSTAKA}

1. Alamsyah, Y. 2008. Membuat Sendiri Frozen Food : Sosis Tanpa Bahan Pengawet. Gramedia. Jakarta. 
2. Apriyantono, A., J. Hermanianto, dan N. Wahid. 2007. Pedoman ProduksiPangan Halal. Khairul Bayan Press. Jakarta.

3. Hames, B. D. 1998. Gel Electrophoresis of Proteins. Oxford University Press. New York USA.

4. James D. and Howland K., 1997, Protein Purification and Analysis, Research school of Biosciences, University of Kent Canterbury, UK.

5. Li, Z., O. Agbulut, G. Butler-Browne, G. Carlsson, \& D. Paulin. 1997. Desmin is Essential for the Tensile Strength and Integrity of Myofibrils but Not for Myogenic Commitment, Differentiation and Fussion of Skeletal Muscle. Journal of Cell Biology 139 (1) : 129-144.

6. Lowry et. Al., 1959 Method of Enzymology, vol. 182. Academic Press, USA.

7. Nazar, D. S. 2007. Keragaman molekuler dan karakterisasi miosin otot skeletal sapi, kambing dan babi. Tesis: Universitas Airlangga. Surabaya.

8. Suryaningsih, L. 1997. Pengaruh daging tetelan, samcan dan punuk dari bangsa sapi australian commercial cross terhadap pembentukan sosis. Tesis: Program Pascasarjana IPB. Bogor.

9. Susanto, E. 2006. Identifikasi Pencampuran Daging Dalam Baso. http://202.155.15.208/suplement/cetak_detail.a sp?mid=5\&id=219274\&kat_id=105\&kat_id1= 147\&kat_id2=218.www.republika.com. Artikel diakses pada tanggal 20 Juni 2008.

10. Wahniyathi, H dan H. M. Ali. 2005. Karakteristik protein daging dengan penambahan $\mathrm{NaCl}$ pada berbagai waktu aging post mortem dan hubungannya dengan mutu sensori sosis. Tesis: Fakultas Peternakan Universitas Hasanudin. Makasar. 